\title{
Creating Tomorrow's Global Entrepreneurs: A Case Study of the Stu Clark Centre for Entrepreneurship
}

\author{
Malcolm C. Smith and Mavis McRae
}

\author{
"When I went to university, we didn't have these opportunities." \\ We just took 'regular' business courses and then, when we \\ started a business, we learned from the School of Hard Knocks. \\ Stu Clark \\ Entrepreneur and Philanthropist
}

\begin{abstract}
This article presents a case study of the University of Manitoba's Stu Clark Centre for Entrepreneurship. The Centre provides experiential entrepreneurial training for youth as well as undergraduate and MBA students. The article describes the various programs the Centre is involved with both locally and internationally. These include preparing students for investment competitions, entrepreneurship day camps for at-risk youth, undergraduate entrepreneurship student exchange, and national and international training of entrepreneurship teachers.
\end{abstract}

\section{Introduction}

The Stu Clark Centre for Entrepreneurship (hereafter referred to as "the Centre") is housed in the I.H. Asper School of Business' Department of Marketing at the University of Manitoba in Winnipeg, Canada (see Figure 1). Its major focus is to encourage the development of new businesses and global entrepreneurship thinking among young adults and youth by encouraging them to consider entrepreneurship as their life's calling. Thus, the Centre's mission is to create a new breed of entrepreneurs by means of experiential education. This article discusses the successful programs developed and implemented at this major Canadian business school to foster and promote entrepreneurship at local, national, and international levels among youth and young adults. The article also shares some of the challenges faced and lessons learned by the Centre.

\section{Background}

The Stu Clark Centre (umanitoba.ca/entrepreneur/) was founded in 1989 as the Asper Centre for Entrepreneurship and renamed the Stu Clark Centre for
Entrepreneurship in 2008 in recognition of Mr. Stu Clark, a successful entrepreneur alumnus of the University of Manitoba, who made a major financial gift to support the Centre. While the mission of the Centre is to provide general entrepreneurship training, the Centre has two major foci: i) developing entrepreneurs on a local/national level and ii) developing entrepreneurs on an international level. The first focus fulfils the desires of the founder of the Centre, Mr. Israel Asper, and the namesake/benefactor, Mr. Stu Clark who both wished to have entrepreneurship courses offered in the Business School's curriculum and to the local/national community since they did not have the opportunity to have such formal training. Subsequently, sponsorship funds are directed to encourage entrepreneurship a career choice for university students and youth in the province of Manitoba. The second focus follows one of the University of Manitoba's directives, which is international collaboration. While the I.H. Asper School of Business had various international initiatives, the Centre's activities in the international arena include partnering with universities outside Canada as well as aiding in the training of entrepreneurs in developing countries, as will be discussed later in this article. 


\section{A Case Study of the Stu Clark Centre for Entrepreneurship}

\section{Malcolm C. Smith and Mavis McRae}

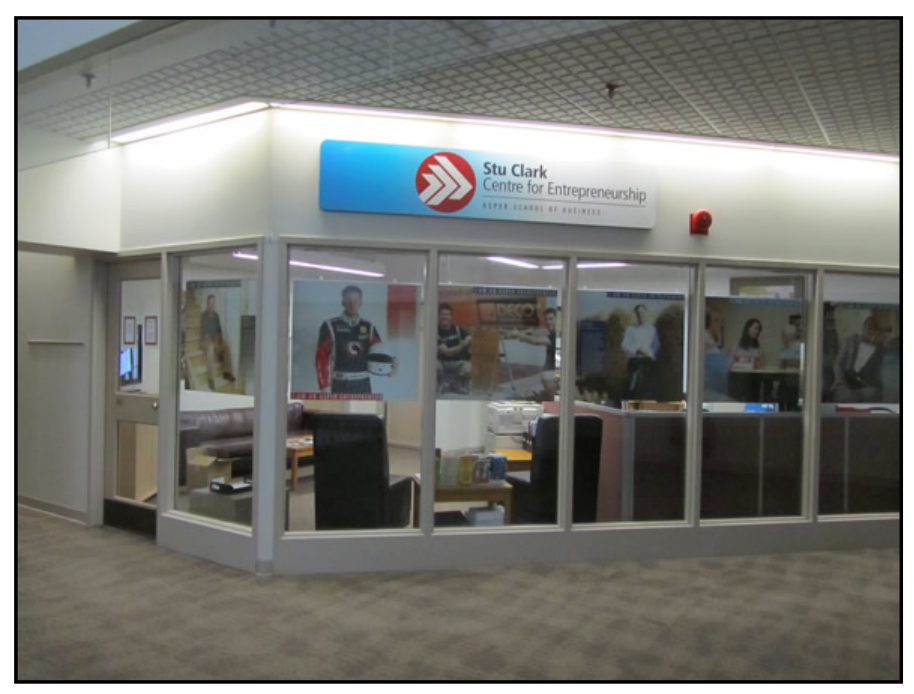

Figure 1. The Stu Clark Centre for Entrepreneurship

The Centre operates with an Executive Director and up to four staff members. Students involved with the Centre are mentored by a local Entrepreneur-inResidence. Additionally, two successful entrepreneurs from the United States act as International Entrepreneurs-in-Residence. They visit the Centre two times each year and spend time advising students and speaking with the local business community. The Centre has an Advisory Board consisting of local and international entrepreneurs, faculty members from the Asper School of Business and four international universities, and major funders who support the Centre financially.

With a budget of approximately $\$ 800,000$, the Stu Clark Centre for Entrepreneurship currently supports a variety of national and international programs aimed at youth as well as university students and adults. The Centre's major programs are described below.

\section{Business Planning Development and Business Plan Competitions}

\section{International competitions}

Each year, the Stu Clark Centre guides undergraduate and MBA student teams in preparing a business plan for a new enterprise and some teams go on to compete in local and international investment competitions. Students develop their business plans during the Fall Semester in their "New Venture Analysis" course and the students who develop the top-ranked plans go on to represent the Stu Clark Centre and the University of
Manitoba at the investment competitions, which usually take place from February through May. Many of these competitions are held in the United States (e.g., Atlanta, GA; Cincinnati, OH; Louisville, KY; Portland, OR), but some are hosted by universities in such countries as Brazil, Hong Kong, and Thailand. Judges for these competitions are typically successful venture capitalists and angel investors. The business plans are for a wide variety of ventures, but an emphasis is placed on startups for high-technology initiatives. The ideas for these specific startups have often come from the local scientific business community such as the Winnipeg National Research Council office. The teams are coached by staff members and the local and international Entrepreneurs-in-Residence who have experience in launching high-tech companies.

Since the Centre began participating in these events, its students have won 48 first-place finishes at competitions in Europe, Asia, South America, and across North America. In doing so, the student teams have won in excess of $\$ 1$ million in cash and in-kind prizes. Perhaps more importantly, over 30 businesses have been launched by our student teams based on these business plans, which employ over 500 people and they have raised in excess of $\$ 30$ million. Examples of successful startups that have sprung from the Stu Clark Centre are NovaDAQ Medical Technologies (novadaq.com) and CrackBerry (crackberry.com). The complete story of CrackBerry can be found at crackberry.com/crack-team.

\section{The Stu Clark Venture Challenge}

In 2004, the Centre launched its own investment competition - the Stu Clark Investment Competition (tinyurl.com/cd9tebp) - which takes place at the end of March each year and has attracted teams from Canada, the USA, Brazil, and Thailand. This competition consists of a tradeshow, an "elevator pitch" competition and the formal presentation and defense of business plans. Grand winners of the Stu Clark Investment Competition gain a place in the Venture Lab Investment Competition (formerly MOOT Corp. Global Competition), which is considered the "Super Bowl" of business planning competitions. Past winners have also been invited to close NASDAQ in New York City in the late summer.

\section{Nicol Entrepreneurial Award Competition}

The Stu Clark Centre annually participates in the Nicol Entrepreneurial Award Competition (nicol-award.com), which is a Canada-wide entrepreneurship competition 


\section{A Case Study of the Stu Clark Centre for Entrepreneurship}

\section{Malcolm C. Smith and Mavis McRae}

founded by Wes Nicol for university undergraduate students from any discipline. The competition requires individuals to present a business plan to a panel of judges which is video-taped. Students from Engineering, Arts, Architecture, and Business have participated in the past at the University of Manitoba. The winner of this local competition has their business plan and video forwarded as a national semi-finalist and the videos are reviewed by a panel to select the six national finalists. Finalists travel to Ottawa, Canada to present and defend their plans in front of a panel of judges.

\section{Manitoba High School Business Plan Competition}

The Stu Clark Centre also hosts the Manitoba High School Investment Competition (tinyurl.com/csqk9wz), which is held at the end of April each year and is open to any secondary school student in the province. As individuals or in teams of up to three, students present business plans, participate in a tradeshow, and give an elevator pitch of their new business idea. The winner(s) receive a $\$ 2000$ scholarship for post-secondary education at any business program offered in Manitoba.

\section{Entrepreneurship Education for Youth}

Since 1998, the Centre has run summer entrepreneur "day camps" at the Asper School of Business aimed at youth who are at risk. These camps are offered free of charge to the participants and include transportation to and from the university and lunch each day (funded by sponsors).

Prior to 2011, these camps were known as the Curry BizCamp in Entrepreneurship and were offered for two age groups. The first group was Winnipeg youth aged 12 to 14 years old. This group's one-week camp involved lessons on how to start and run a small business. The camp also included an experiential exercise in which students were given start-up money to purchase materials to make arts-and-crafts products. These products were then sold at a local outdoor market and the students were allowed to keep their profits (see Figure 2). As a final exercise, the students gave presentations about what they had learned from this endeavor.

The second age group included 15 to 18 year-olds who participated in a two-week day camp. These students were not only taught the fundamentals of starting a small business, but also how to develop a business plan. They were coached on presentation skills and were then required to present their business plan to a

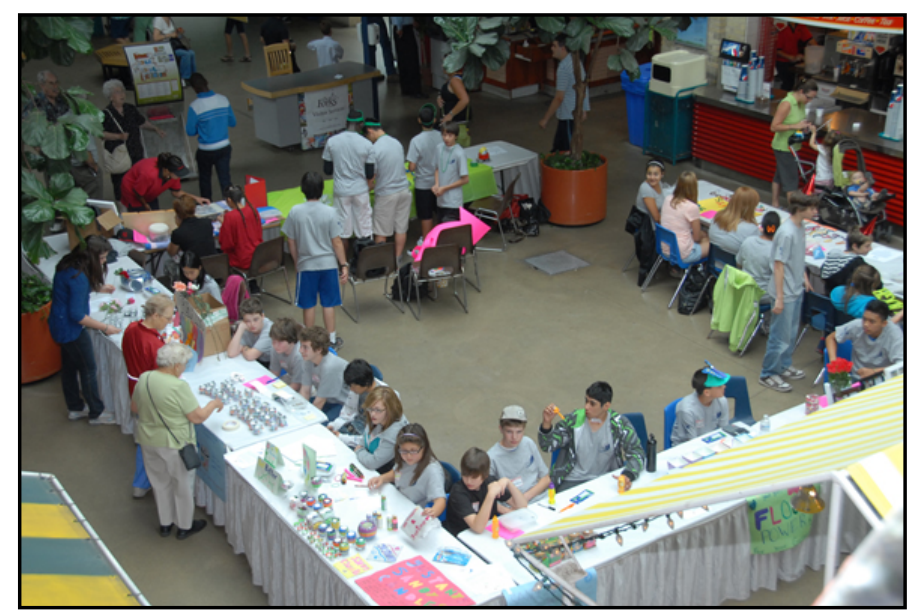

Figure 2. BizCamp students selling their wares

panel of local judges, and winners received a cash prize. The end of the camp culminated with an official graduation ceremony where certificates of participation were presented to each student.

In 2011, the format of the day camp was changed, as well as the name. Now called the "New Venture Adventure" (tinyurl.com/blpyynv), the day camp is for 10 to 12 year olds. Camp participants learn how to be true entrepreneurs through a variety of activities and classroom lessons, and they have a chance to create their own retail business. This camp (as well as the former BizCamp) is taught by locally trained entrepreneurship instructors at the Asper School of Business during the summer vacation. The young students cover basic marketing, opportunity recognition, break-even analysis, presentation skills, and learning what it takes to be an entrepreneur. This is done via formal classes and exercises, class trips, and guest speakers from the local business community. Students from the New Venture Adventure camp also develop and present a business plan. They then participate in a sales competition that begins with students receiving a small cash base to invest in their business idea. The students then go en masse to a large retail outlet where they purchase supplies with their investment funds. After returning to the business school, the students "manufacture" their products (e.g., jewelry, greeting cards, picture frames), which they then sell to the public. As an incentive, they are allowed to keep their profits. The program also involves a retail evaluation exercise where the students travel to a local shopping mall and compare and evaluate different types of retail outlets ranging from large department stores to small independent operations. 


\title{
A Case Study of the Stu Clark Centre for Entrepreneurship
}

\author{
Malcolm C. Smith and Mavis McRae
}

\section{North American Mobility Program for Undergraduate Business Students}

The Stu Clark Centre is part of the North American Mobility Program in Higher Education (tinyurl.com/d6dwgbm) is a consortium of North American business schools that exchange undergraduate business students for a semester. Two universities from Canada (University of Manitoba and Laurentian University), two from the USA (University of North Dakota and the State University of New York at Plattsburg), and two from Mexico (Guadalajara and Nuevo León) are participating in this project. The Mobility Program began in 2011 and is funded by a grant from Human Resources and Skills Development Canada (HRSDC).

The purpose of this program is to further develop students' professional mobility by acquiring the skill sets, experiences, and knowledge base necessary to understand, analyze, develop models for, and practice entrepreneurship in Canadian, Mexican, or US markets. As part of this program, the exchange students take undergraduate courses in product planning and development, new venture analysis, and other entrepreneurship courses at their home and host universities. In doing so, the students not only learn about doing business and living in other cultures, but they also make valuable contacts around North America.

During the Fall 2011 Semester, 11 students from the Asper School of Business, the United States, and Mexico participated in the Mobility Program at the University of Manitoba. A highlight of the semester was the "New Product Planning and Development Tradeshow" where groups consisting of students from a mix of the participating universities presented their ideas for a new product launch in a tradeshow format (see Figure 3). This was held in conjunction with a faculty symposium attended by seven professors from the American and Mexican partner universities. Students from each institution will be eligible to go on exchange to the other member universities for the next three years.

\section{International Partners}

The Stu Clark Centre partners with various universities from around the world. In doing so, the Centre exchanges program ideas and best practices with its partners. Past and present partners include universities from the United States (e.g., University of Michigan,

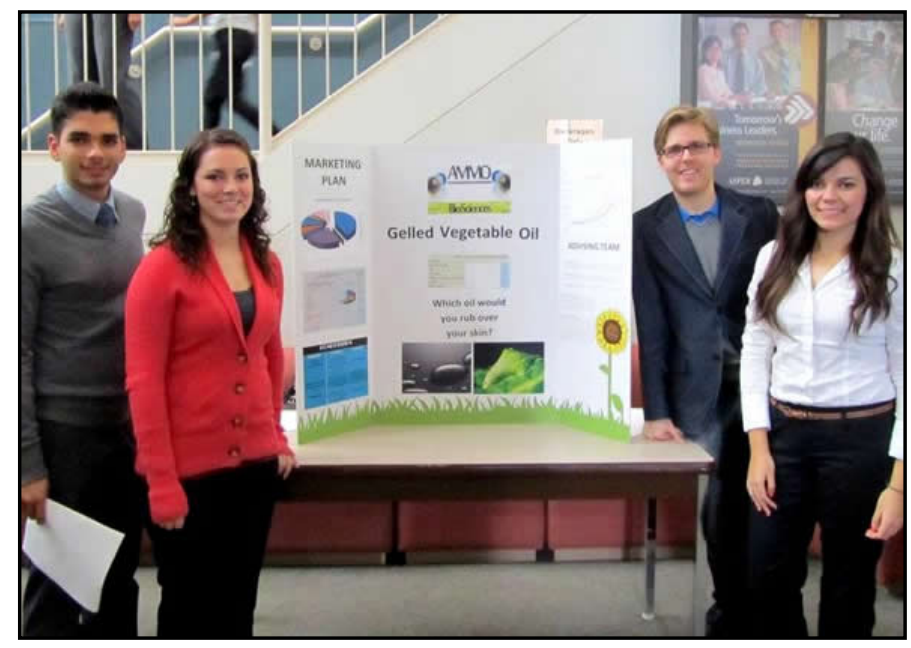

Figure 3. Participants in a North American Mobility tradeshow

University of Oregon, Rice University, University of Texas at Austin), Ireland (Queen's College Belfast), France (Groupe ESC Troyes), Brazil (Fundacao Getulio Vargas), Japan (Akita University), and the Philippines (De La Salle University).

\section{Training of Entrepreneur Teachers}

As part of the Paul Martin Aboriginal Education Initiative (maei-ieam.ca), the Stu Clark Centre also participates as a site for teacher training in entrepreneurship. Three times per year, secondary school teachers from across Canada come to Winnipeg to be trained over four days on how to teach the typical secondary-school curriculum in entrepreneurship. Teachers who participate in this program must come from a school where there is a large aboriginal student enrolment. The goal of the Paul Martin Aboriginal Education Initiative is to encourage aboriginal students to continue their education and to provide them with the skills to start their own business.

\section{International Outreach}

On an international scale, the Stu Clark Centre sends specially trained instructors to international locations to train local adults to become teachers of entrepreneurship. The Canadian Trade Commissioner Service (TCS MANIL) in Manila, Philippines identified a need to conduct training in entrepreneurship for the indigenous people of the Philippines who are located in areas hosting mining companies. The TCS contacted the Centre about introducing the Curry BizCamp in 


\title{
A Case Study of the Stu Clark Centre for Entrepreneurship
}

\author{
Malcolm C. Smith and Mavis McRae
}

Entrepreneurship program to the Philippines, specifically to help the indigenous people develop their business interests to create sustainable economic plans, for now and after the mines are exhausted. The Philippine BizCamp project, with support from TCS MANIL and the Centre, was launched in September 2010.

The first step in bringing BizCamp to the Philippines was a "Train the Trainers" workshop that created a pool of 21 certified BizCamp trainers (see Figure 4). This session was delivered by the Executive Director of the Centre and a Manitoba teacher certified to train new trainers. The newly graduated BizCamp instructors then conducted a three-week pilot run of the Philippine BizCamp. Three mining project sites located in Mindanao's Caraga regions were chosen to host the pilot BizCamps. Participants involved 30 members of the Mamanwa and Manobo tribes of varying ages and educational backgrounds. The trainers held the first two weeks of classes at the mine sites where participants learned about business basics, spoke with local entrepreneurs, and toured various businesses. The final week brought the three groups together in Surigao City where they prepared their business plans, met with coaches and received feedback, and conducted market research outside their home territory at the local public market. The groups presented their business ideas to a panel of volunteer judges from the business, financial, and mining sectors. Business plans included retail products based on their traditional tribal beadworks, tilapia fish farming, ginger farming, and handicrafts making use of indigenous water lily and romblom grass. Three teams proceeded to the final round of the competition where they presented their plans in front of an audience of over 100 family and friends as well as business and government representatives.

The highlight and reward for the participants' efforts was the opportunity to "graduate" from the BizCamp program wearing graduation gowns and caps to a traditional graduation ceremony in the presence of family, friends, and the business community. This highly emotional event represented the first time many of the indigenous people had participated in a graduation ceremony, since most of them never finished high school (See Figure 5).

Many additional success stories emerged from the event. During the market research trip to Surigao public market, five of the nine teams secured initial

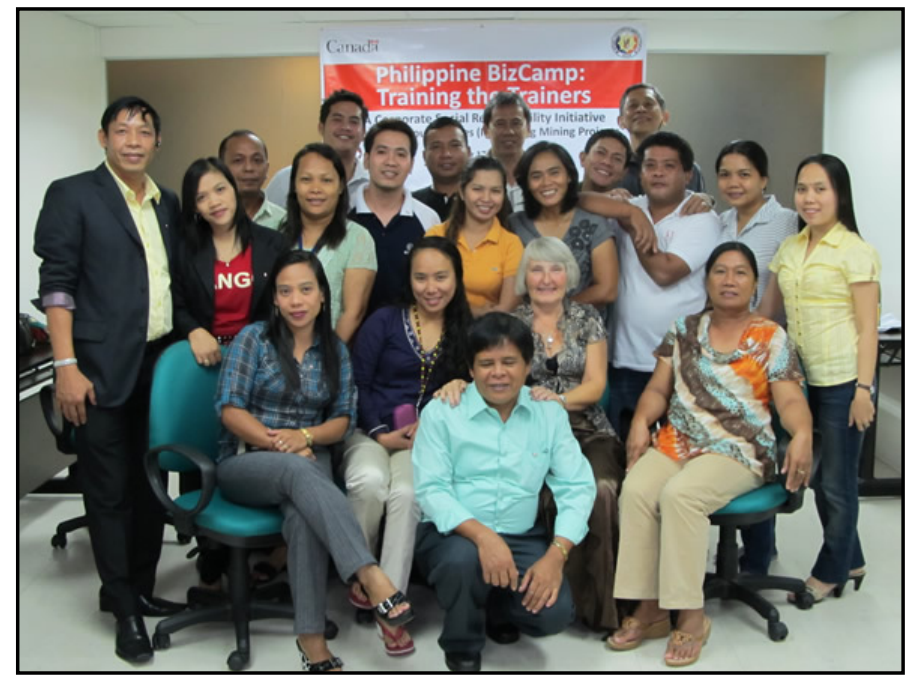

Figure 4. Philippine BizCamp Trainers with their Canadian instructor

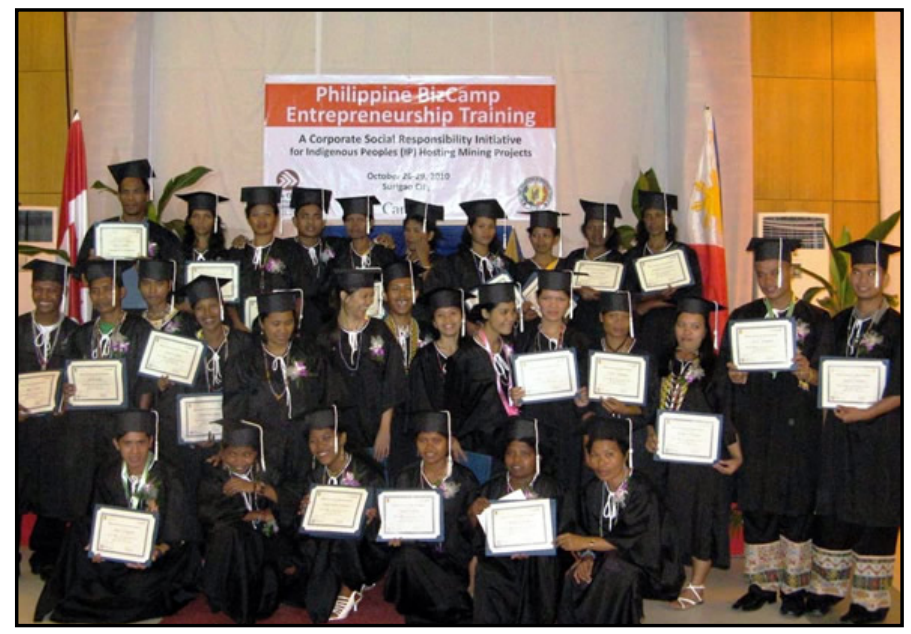

Figure 5. Graduates of the Phillipine BizCamp

orders for their product. This expanded the teams' market reach to bring in revenue from outside their community. The tilapia team expanded their product ideas from growing and selling whole fish to valueadded products such as fish balls and smoked fish, and they eventually secured angel financing for their business. The ginger farming team acquired start-up capital from the tribal chiefs who attended the business plan presentation. The pilot project was considered a success and the future expansion of Philippine BizCamp is now under development. 


\title{
A Case Study of the Stu Clark Centre for Entrepreneurship
}

\author{
Malcolm C. Smith and Mavis McRae
}

As a result of the success of this program, the Canadian Trade Commission expressed interest in developing a similar program in Vietnam and similar teacher training took place there in February, 2012.

\section{Lessons Learned}

While the Stu Clark Centre for Entrepreneurship has had success on many fronts since its foundation in 1989, this has not come without challenges which vary from year to year.

In particular, sustained sponsorship for the youth day camps is a challenge. Many sponsors want to see tracking of success such as the number of "graduates" of these programs who go on to be entrepreneurs. Tracking of this age group is nearly impossible since many do not keep in touch with the Centre or do not respond to attempts to track their education or career choices. Many of the participants of summer day camps are from lower-income families who tend to move quite often. This makes tracking of past participants even more difficult. Additionally, privacy issues can impede the reporting of any successes to donors unless the participants grant permission the Centre to release information about them. For some programs, there is over demand and the sponsorship funds are not sufficient to allow all applicants to participate.

The Centre faces additional challenges with the formation of new teams each year to compete in the international business plan competitions. Student numbers and skills vary from year to year. Thus, a large pool of candidates with not only the ability but also the dedication and willingness to commit time and effort on top of their regular studies is ideal, but not always available.

Furthermore, finding "investible" ideas for business plan development is always a challenge in the city of Winnipeg and the Manitoba community. It is essential to have an "investment-worthy" idea (i.e., one that would be sustainable or applicable to a large market) as opposed to a "small-business" idea. Judges at the competitions are often angel investors, venture capitalists and investment bankers who are looking for high rates of return. The best potential businesses for these competitions tend to be in the high-technology area. Subsequently, much time and effort is required from the Centre's staff to seek out these business opportunities before the preparatory course begins in the fall semester. Often, the ideas for new businesses come from the University of Manitoba's Intellectual Property Office or the local scientific community.

\section{Conclusion}

Through its various endeavors, the Stu Clark Centre carries out its goal of encouraging the development of new businesses and global entrepreneurship. It does so not only by training youth and students to develop new businesses, but the Centre also facilitates exchange of university entrepreneurship students as well as national and international training of teachers of entrepreneurship. While its accomplishments have come with challenges, its success to date can be measured in terms of the number of competitions its teams have won, the number of businesses that have been started as a result of its training programs, and the accomplishment of training teachers of entrepreneurship in the Philippines and Vietnam in addition to those trained in Canada.

There is a growing need for entrepreneurs - on both a local and international scale. The Stu Clark Centre for Entrepreneurship looks forward to continuing to play a role in creating tomorrow's global entrepreneurs.

\section{About the Authors}

Malcolm Smith is the Head of the Department of Marketing at the University of Manitoba's I.H. Asper School of Business. From 1999-2004, Dr. Smith was Associate Dean (Research and Graduate Programs) in the Asper School. He has been a visiting professor at universities in the Ukraine, Taipei, Bangkok, and Oregon, USA. Dr. Smith was also the Director of the Asper School's International Student Exchange Program from 2004-2007. Dr. Smith received his BScH and MBA from Queen's University and his PhD from the University of Oregon. His research has been presented at numerous national and international conferences and published in various journals.

Continued on next page... 


\section{A Case Study of the Stu Clark Centre for Entrepreneurship}

Malcolm C. Smith and Mavis McRae

\section{About the Authors (Continued)}

Mavis McRae is the Entrepreneur-in-Residence and Acting Director of the Stu Clark Centre for Entrepreneurship. She has been an independent consultant since 2005, specializing in the areas of product development and food safety, project management, and new business development. Mavis holds a BSc in Food Science and an MBA in Marketing and Small Business from the University of Manitoba. She further developed her technical and business skills at the Food Development Centre, Prairie Centre for Business Intelligence, and the National Research Council's IRAP program. She has lectured at the University of Manitoba and Nanjing University of Finance and Economics. Mavis has been involved in three start-up businesses in the last 12 years including the Two Rivers Brewing Company and Lucky Dog Biscuits, a natural, human-quality pet treat company. Presently, she is developing the North American market for a bioplastic technology company called Solanyl Biopolymers Inc. 